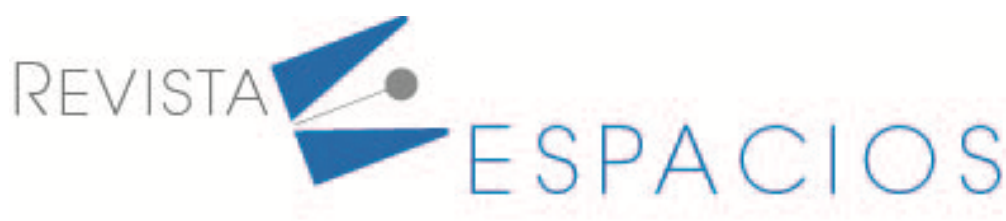

\title{
Higher order thinking skills of students in Bangkok, Thailand
}

\author{
Habilidades de pensamiento de orden superior de los estudiantes en Bangkok, Tailandia \\ BOOBPHAN Kanchana ${ }^{1}$ \\ BOONCHAN Sisan ${ }^{2}$ \\ PARIYAPORN Tungkunanan ${ }^{3}$
}

\begin{abstract}
The aim of this research project is to study the factors that affect the higher order thinking skills of students in Bangkok, Thailand. The participants of this research project are 14 experts in education, selected with an intentional sampling technique. From the interviews with the experts, the 4 factors that affect the students' higher-order thinking skills were determined: classroom environment, achievement motives, internal locus of control, and parenting. Keywords: Higher order thinking, factors affecting skills, student thinking skills.

Keywords: higher order thinking, factors affecting skills, student thinking skills.

Resumen

El objetivo de este proyecto de investigación es estudiar los factores que afectan las habilidades de pensamiento de orden superior de los estudiantes en Bangkok, Tailandia. Los participantes de este proyecto de investigación son 14 expertos en educación, seleccionados con una técnica de muestreo intencional. A partir de las entrevistas con los expertos se determinaron los 4 factores que afectan las habilidades de pensamiento de orden superior de los estudiantes: ambiente del aula, motivos de logro, locus de control interno y crianza de los hijos.

Palabras clave: pensamiento de orden superior, factores que afectan las habilidades, habilidades de pensamiento del estudiante.
\end{abstract}

\section{Introduction}

Higher order thinking skills are essential for students in 21st century. Lacking of higher order thinking skills will affect students' ability of problem solving. Students cannot solve problems that are complicated. The education system is a key variable that help human beings develop skills for the new century (Perdana et al., 2020). Cultivating the student's ability to think at a higher level has been an important theme for redesigning and reforming learning systems (Kim, 2005). Moreover, learner-oriented education is the system provides to all learners the opportunities to acquire more knowledge and experience and to enhance the capacities of every learner to the fullest extent in terms of intelligence and ability of recognition, which allows learners to use their thinking skills to solve and analyze problems and synthesize knowledge (Vongtathum,2015).

\footnotetext{
${ }^{1}$ Educational Administration. Faculty of Industrial Education and Technology. King Mongkut's Institute of Technology Ladkrabang. 57603003@kmitl.ac.th

2 Educational Administration. Faculty of Industrial Education and Technology. King Mongkut's Institute of Technology Ladkrabang

${ }^{3}$ Educational Administration. Faculty of Industrial Education and Technology. King Mongkut's Institute of Technology Ladkrabang
} 
Higher order thinking skill is the ability to handle data or contents that have been obtained, which has to go through many steps and relies on thinking strategies that are more complicated, insightful and creative in processing several bodies of knowledge (Zohar \& Schwartzer, 2005), including the opinion generation, research question asking, comparison, and management of argument to research hypotheses to cover all issues. It is necessary to rely on thinking to handle data. Thus, everyone should receive supports through learning and teaching in order to develop personal higher order thinking skills (Heong et al., 2012) because higher order thinking skills lead to the development of intelligence (Burke \& Williams, 2012).

It is apparent that higher order thinking skill is a key factor that affects the development of the quality of learners so that they will be Human Resources that play important roles in developing the country. Many academics and researchers in the international level and at the contexts of Thailand have been trying to study on the bodies of knowledge relating to this matter. An example is the work by Saido et al., (2018), entitled 'Higher Order Thinking Skills Among Secondary School Students in Science Learning'. The findings from their work can soundly confirm that higher order thinking skill is essential for effective learning and is a key goal of the education that mainly focuses on urging the higher order thinking skill of learners. In addition, Kusaeri, Hamdani \& Suprananto (2019) have studied on 'Student Readiness and Challenge in Completing Higher order Thinking Skill Test Type for Mathematics' the findings from which point out that students who lack of higher order thinking skills cannot solve mathematics problems that have multiple answers nor can they explain the causes and effects. This point is concurrent with the discovery by Hadi et al. (2018) that students who are not accustomed to higher order thinking skills and lack of problem-solving skills cannot overcome the challenges from complicated mathematics problems.

In Thailand, the Ministry of Education of Thailand has announced the policy that includes the goal of student development in the National Education Plan, with the emphasis on developing all students to have characteristics and skills of learning in the $21^{\text {st }}$ century, which promotes teaching and learning that enable students to have critical thinking skills and problem-solving skills, which will lead to the development of higher order thinking skills (Office of the Education Council (ONEC), 2017). Likewise, as for education arrangement by Bangkok Metropolitan sets the policies for education arrangement, is aware of the importance of education arrangement, and thus is committed to developing education to enhance the quality of children in the local areas, with the emphasis on thinking process in all dimensions, especially higher order thinking skills of students under the Bangkok Metropolitan, in order that students will have qualities that are internationally accepted (Department of Education, Bangkok Metropolitan, 2016). On the other hand, considering the effectiveness in terms of education quality of students under Bangkok Metropolitan, it is apparent that the students under Bangkok Metropolitan are still facing with the precise problems of higher order thinking skills. Based on the report from the Organisation for Economic Co-operation and Development (OECD) in 2018, the results from the Programme for International Student Assessment (PISA) show that the average scores of students in Thailand are lower than the means of students of other members of OECD in the dimensions of reading, mathematics and sciences. Such problems are caused by students' lacking of skills of reading, thinking, and problem solving (OECD, 2018). The results from the aforementioned test concur with the results from the Ordinary National Education Test (O-NET) held by the National Institute of Educational Testing Service (NIETS) (Public Organization), Thailand, which has reported that the overall outcomes in the subjects of mathematics, sciences and English language of the students of the entire country are not satisfying because the average scores of each of all the aforementioned subjects are lower than 50 percent. This is because students still lack higher order thinking skills; thus, they cannot solve complicated problems (NIETS, 2018). However, many educators in Thailand have studied the problems with the higher order thinking skills of students in different methods. There are various types of higher order thinking skills, which have been explained in many related documents, research works and theories, in different contexts (Dethom \& Thotla, 2018). 
Therefore, the research aims to synthesize the components of higher order thinking skill and to examine the factors affecting higher order thinking skills of students in Bangkok, Thailand, by interviewing university students, scholars and researchers on their opinions in order to attain details of Components of Factors with Effects on Higher Order Thinking Skills of Students in Bangkok, Thailand, in accordance with the natures of the contexts of the area. The findings from the research work can be applied as the directions for the development of the students, the designing of teaching and learning, the development of quality and strategies of schools that develop higher order thinking skills of and quality of education for students under Bangkok.

\section{Methodology}

Step 1: The Synthesis of Higher Order Thinking Skills components. This step work is synthetic research with documentary analysis on documents that are related to higher order thinking skills, which are principles, theories and academic journals from publishers that are internationally reliable and acceptable by applying the research synthesis process suggested by Wiratchai (2000).

Step 2: The interviews with the education experts in order to study the factors affecting higher order thinking skills of students in Bangkok,Thailand. Participants for this step are 1 administrator in the policy level of the Office of Basic Education Commission, 1 administrator in the policy level of the Department of Education, Bangkok Metropolitan, 2 supervisors under the Area Primary Education Offices in Bangkok, 4 administrators of schools under Bangkok Metropolitan, 4 teachers in elementary level from schools under Department of Education, Bangkok Metropolitan, and 2 scholars in the field of learning arrangement, the total number of which is 14 , selected with purposive sampling technique. A semi-structured interview scrip is designed on the bases of the approaches of components of higher order thinking skills from the research works by Ramos et al., (2013), Lewis \& Smith (1993), Rajendran \& Idris (2008), Tanujaya (2017), Wang and Wang (2011), Marzano (1993) and Brookhart (2010), and the approaches of factors affecting higher order thinking skills from the research works by Pascarella et al., (2013), Budsankom et al., (2015), O'Tuel and Bullard (2001), Marshall \& Horton (2011) and Vongpattaratrap (2014). The results from the aforementioned research works are synthesized in order to generate questions all of which are checked and verified in order to assure the questions by 5 experts so that the questions can be used in the tool that is used for data collection. Data analysis includes content analysis technique suggested by Johnson \& LA Montagne (1993), which incorporates 5 steps, namely: Data preparation, Data familiarization, Identification of units of analysis, Setting of tentative categories, and Verification of categorization.

\section{Results}

Research findings are divided into 2 parts consisting of 1) results from the Synthesis of Higher Order Thinking Skills components and 2) results from the interviews with the education experts in order to study on factors affecting higher order thinking skills of students in Bangkok Thailand. The findings are as follows.

Part 1: Results from the Synthesis of Higher Order Thinking Skills components are shown in Table 1. 
Table 1

Results from the Synthesis of Higher

Order Thinking Skills components

\begin{tabular}{|c|c|c|c|c|c|c|c|c|c|c|c|c|}
\hline $\begin{array}{l}\text { High Order Thinking } \\
\text { Components }\end{array}$ & 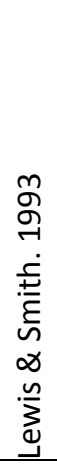 & 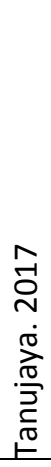 & 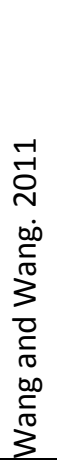 & 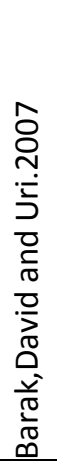 & 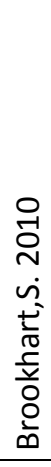 & 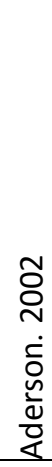 & 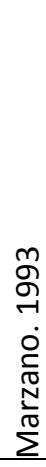 & 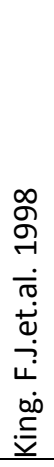 & 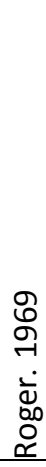 & 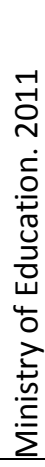 & 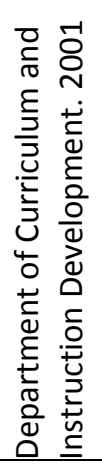 & $\begin{array}{l}\bar{\pi} \\
\stackrel{0}{0} \\
\end{array}$ \\
\hline Systematic Thinking & & $*$ & $*$ & $*$ & & & $*$ & & & & & 4 \\
\hline Critical Thinking & $*$ & $*$ & $*$ & $*$ & $*$ & $*$ & $*$ & $*$ & $*$ & & $*$ & 10 \\
\hline Creative Thinking & & $*$ & & $*$ & & $*$ & $*$ & $*$ & $*$ & $*$ & & 6 \\
\hline Problem Solving Thinking & $*$ & & & $*$ & $*$ & & $*$ & & & & $*$ & 5 \\
\hline Analytical Thinking & & & & & & & $*$ & & & $*$ & & 1 \\
\hline Thinking Design & & & $*$ & & & & & & & & & 1 \\
\hline Thinking Link & & & & $*$ & & & & & & & & 1 \\
\hline Metacognition & & & & & & & & $*$ & & & & 1 \\
\hline Decision Making & & & & & & & $*$ & & $*$ & & $*$ & 3 \\
\hline Judgmental Thinking & & & & & & & & & & $*$ & & 1 \\
\hline Rational Thinking & & & & & & & & & & $*$ & & 1 \\
\hline Scientific Thinking & & & & & & & & & & $*$ & & 1 \\
\hline
\end{tabular}

From Table 1, the results from the Synthesis of Higher Order Thinking Skills components show that there are 12 types of higher thinking skills mentioned by academics. However, there are only 3 components that have been rated with 5 marks or more, which are critical thinking, creative thinking and problem-solving thinking.

Part 2: Results from the interviews with the education experts in order to study factors affecting higher order thinking skills of students in Bangkok Thailand. The findings are as follows.

\section{Factor of Classroom Ambience}

An example of the data is as follows, "The classroom ambience should mean that the classroom is clean and has academic ambience, teachers are friendly and understand students, the teaching is not too serious or stressful, students are allowed to fully show their potentials, and the used instruments are appropriate to teaching and learning."

\section{Factor of Achievement Motives}

An example of the data is as follows, "...with concentration and responsibility in working in order to achieve work with high quality, do not believe in luck, know how to plan for work, and need achievement."

\section{Factor of Internal Locus of Control}

An example of the data is as follows, "...has the characteristics of learning loving, interested in environs, eager to know about things in the environment that can be beneficial in the future, and attempt to succeed in everything although it is difficult." 


\section{Factor of Parenting}

An example of the data is as follows, "...allowing the children to receive warmth fully, to do what they love and decide to do themselves and to participate in all activities. Children should be trained to work and have selfresponsibility, to think together rather than to be told what is right or wrong, to be open-minded, to listen to others and to have positive attitude."

\section{Discussions}

\subsection{The Synthesis of Higher Order Thinking Skills components}

The results show that the skills consist of critical thinking, creative thinking and problem-solving thinking. The findings from the study show that the element of critical thinking has the highest frequency which means this element has been mentioned by most academics studied on. This is because critical thinking is the thorough and prudent consideration that leads to a decision (Ennis, 1985). It also includes the prudent assessment of the situation and the linkage of issues and problems in order to determine all actions correctly and properly (More \& Parker, 1986). This concurs with the studies by Lewis \& Smith (1993) and Tanujaya et al., (2017) who have confirmed that critical thinking is a significant element of higher order thinking skills. Also, the findings from this study show that creative thinking is an element with high frequency. This is because creative thinking is the capability of problem solving with in-depth thinking (Torrance, 1962). It also incorporates the setting and testing of hypotheses and skills of communication of meanings and ideas that are new, valuable and acceptable to others (Even et al., 1987). The outcomes from the synthesis that concern the element of creative thinking are supported by the studies by Mazano (1993), King et al. (1998), and Roger. (1969). These scholars have confirmed that creative thinking is an important element of higher order thinking skills as well. As for problem-solving thinking, it is a type of learning that relies on two or more principles that are interrelated with one another and combine such principles to form a new capability called problem solving thinking (Good, 1973). Lewis \& Smith (1993), Barak et al., (2007) and Mazano (1993) have defined in their studies that problem-solving thinking is an essential element of higher order thinking skills. Therefore, educational agencies should implement these elements of higher order thinking skills to the development of learners for solving the problem of quality of learning and teaching arrangement, especially the building of character and encouragement for learners to have the critical thinking, creative thinking and problem-solving thinking skills so that learners will have desirable characteristics and skills for the $21^{\text {st }}$ century.

\subsection{The interviews with the education experts in order to study the factors affecting higher order thinking skills of students in Bangkok, Thailand}

The interviews with the education experts in order to study the factors affecting higher order thinking skills of students in Bangkok, Thailand, have the details as follows.

\section{Factor of Classroom Ambience}

Classroom ambience factor, especially the component of cleanliness, good atmosphere and supports for learning, affects higher order thinking skills of students because it urges students to have creative thinking (Good \& Brophy, 1991), and to become enthusiastic to perform problem-solving thinking (Frisby \& Martin, 2010). Such findings concur with those from the study by Barr (2016) who discovered that a classroom that is clean and has a good atmosphere can support students' learning, especially the learning that has the challenging nature or has problems that require complicated thinking skills for solving them, which will develop positive classroom ambience (Frisby \& Martin, 2010). The aforementioned classroom ambience will enable students to develop thinking skills. In addition, the component of good relationships among teachers and students will create a good classroom ambience with amiability and mutual supports (Dallimore, Hertenstein \& Platt, 2004). This concurs with the findings from the study by Sidelinger \& Booth-Butterfield (2010) who found out that a good relationship among teachers and students will encourage students to think, express themselves and practice thinking skills in order to develop higher order thinking skills. In addition, students' freedom of expression, teachers' openness to 
students' opinions and the use of equipment that promote higher order thinking skills are the components of classroom ambience factor that affect higher order thinking skills.

\section{Factor of Achievement Motives}

The key component of achievement motive factor is the students' great ambition that makes them persevere to become successful (Haimovitz \& Dweck, 2017) because high ambition will urge students to use their thinking to solve problems and to solve complicated problems requires higher order thinking skills (Ramos et al, 2013). Such findings agree to those from the study by Gropel et al., (2016) who had studied on 'Achievement motive and sport participation' the findings from which led to the conclusion that students with achievement motives will be ambitious and perseverant to solve problems, which are characteristics that enable them to have higher order thinking skills. In addition, students need self-responsibility because an achievement motive is based on selfresponsibility (Lee \& Bong, 2019). This point concurs with the findings from the study by Olivier et al., (2018) who discovered that students who are aware of the competences and highly responsible for themselves are ones with achievement motives and always successful in solving problems because they have good thinking skills and thus are good at analyzing and solving unexpected problems. Furthermore, other components of the factor of achievement motives, namely, patience and ability to make long-term plans are also important.

\section{Factor of Internal Locus of Control}

A key component of the factor of internal locus of control is the attempts to become successful because people who need success will persevere and try to meet their goals (Reknes et al., 2019). This point is concurrent to the findings from a study by Holden et al., (2019) that students with internal locust of control want to and will try hard to become successful. Likewise, Najari et al., (2018) discovered from their study that students with internal locus of control will thrust for success. In addition, enthusiasm is another component of this factor that has been identified because enthusiasm makes students eager to pursue knowledge and find solutions to problems in order to improve themselves, on the basis of internal locus of control that they can do things and can succeed (Van Dinther et al., 2011). In addition, this factor also has other key components, namely, knowledge pursuit and rational thinking.

\section{Factor of Parenting}

A key component of this factor is a democratic parenting style that makes the children feel that they are treated with fairness, not being too spoiled or too oppressed, and accept the abilities and opinions of everyone (Perris et al., 1980). Likewise, Brauer (2016) discovered that the democratic parenting style makes children accept and respect one another. Furthermore, the rational parenting style is another key component of the factor of parenting that develops good thinking skills in children. Such findings concur with those from a study by Wolfradt et al., (2003) who clearly pointed out that a rational parenting style that allows children to ask questions and to give reason for answering questions or explaining things or comparing good points and bad points develops children's thinking and behaviors on the bases of reasoning and rationality. Also, a supportive parenting style is another key component of the parenting factor that affects higher order thinking skills.

\section{Conclusions}

From the findings from the synthesis, it can be concluded that there are 3 components of higher order thinking skills, namely, critical thinking, creative thinking and problem-solving thinking. From the interviews with the education experts in order to study on factors affecting higher order thinking skills of students in Bangkok, Thailand, it can be concluded that 4 factors affecting higher order thinking skills of students in Bangkok, Thailand consist of Classroom Ambience; Achievement Motives; Internal Locus of Control; and Parenting.

Therefore, all the people from all sectors that involve in education arrangement should apply the knowledge of elements of higher order thinking skills as key inputs for setting policies and creating clear strategies for development. Furthermore, teachers can use such information for studying or researching on the matters in order to be able to suggest ways to arrange learning and teaching activities that encourage learners to have higher order thinking skills in the future. The information of the components of factors that affect higher order 
thinking skills is beneficial for administrators of schools, especially those under the Department of Education, Bangkok Thailand, who can use such detailed information for developing administrative strategies for solving problems of the quality of higher order thinking skills that students are facing, by designing programmers or activities of the schools for driving the enhancement of students' higher order thinking skills to achieve goals of the study. If a further study was to be conducted, it is suggested that an exploration of the role of a learning management project as a tool to develop Higher Order Thinking Skills for students should be considered.

\section{Bibliographic references}

Anderson, N. J. (2002). The role of metacognition in second language teaching and learning. Washington, DC: ERIC Clearinghouse on Languages and Linguistics.

Barak, M., David, B. C., \& Uri, Z. (2007). Purposely Teaching for the Promotion of Higher Order Thinking Skills: A Case of Critical Thinking. Res Sci. Educ., 37, 353-369.

Brauer, Jonathan. (2016). Cultivating Conformists or Raising Rebels? Connecting Parental Control and Autonomy Support to Adolescent Delinquency. Journal of Research on Adolescence. 27. (2), 19-27.

Brookhart, S. (2010), How to Assess Higher Order Thinking Skills in Your Classroom. Virginia: ASCD Alexandria.

Budsankom, P., Sawangboon, T., Damrongpanit, S., \& Chuensirimongkol, J. (2015). Factors Affecting Higher Order Thinking Skills of Students: A Meta-Analytic Structural Equation Modeling Study. Educational Research and Reviews, 10(19), 2639-2652.

Burke, L. A., \& Williams, J. M. (2012). Two Thinking Skills Assessment Approaches: “Assessment of Pupils' Thinking Skills" and "Individual Thinking Skills Assessments". Thinking Skills and Creativity, 7, 62-68.

Dallimore, E. J., Hertenstein, J. H., \& Platt, M. B. (2004). Classroom participation and discussion effectiveness Student-generated strategies. Communication Education, 53(1). 103-115.

Department of Curriculum and Instruction Development. (2001). Basic education curriculum documentation manual for learning management Learn science. Bangkok: Kurusapaladprao.

Department of Education, Bangkok Metropolitan. (2016). Basic Education Development Plan, Bangkok Metropolitan, Volume 2 (2017-2020). Bangkok: Agricultural Co-operative Federation of Thailand Printing Press.

Dethom P. and Thotla S. (2018). Guidelines for Development of Higher Order Thinking Skills for Principles of Bangkok Primary Education Service Area Office. Integrated Social Science Journal. 1(10), 158-181

Ennis, R.H. (1985). Alogical basic for Measuring Critical Thinking Skills, Educational Leadership.43 (2): 44-46.

Even, Ellis D., and McCandless Boyd R. (1987). Children and Youth Psychological Development. New York: Holt.

Frisby, B. N., \& Martin, M. M. (2010). Instructor-student and student rapport in the classroom. Communication Education, 59(2), 146-164.

Good, C. V. (1973). Dictionary of education ( ${ }^{\text {rd }}$ ed.). New York: McGraw-Hill Book.

Good, T.I. , \& Brophy, J.E. (1991). Looking in classrooms. New York: Harper \& Row.

Gropel, Peter \& Wegner, Mirko \& Schler, Julia. (2016). Achievement motive and sport participation. Psychology of Sport and Exercise. 27. 93-100.

Hadi, S., Retnawati, H., Munadi, S., Apino, E., \& Wulandari, N. F. (2018). The difficulties of high school students in solving higher-order thinking skills problems. Problems of Education in the $21^{\text {st }}$ Century, 76(4). 
Haimovitz,K.,\& Dweck,C.S.(2017).The origins of children's growth and fixed mindsets : New Research and a new proposal. Child Development, 88(6), 1849-1859.

Heong, Y. M., Yunos, J. M., Othman, W., Hassan, R., Kiong, T. T., \& Mohamad, M. M. (2012). The needs analysis of learning higher order thinking skills for generating ideas. Procedia-Social and Behavioral Sciences, 59, 197-203.

Holden, Shelley \& Forester, Brooke \& Williford, H. \& Reilly, Erin. (2019). Sport Locus of Control and Perceived Stress among College Student-Athletes. International Journal of Environmental Research and Public Health. 16.1-7. Infinity, 8(1), 75-86.

Johnson, L. J., \& LaMontagne, M. J. (1993). Research methods using content analysis to examine the verbal or written communication of stakeholders within early intervention. Journal of early intervention, 17(1), 7379.

Kim, Y. (2005). Cultivating reflective thinking: The effects of a reflective thinking tool on learners' learning performance and metacognitive awareness in the context of on-line learning. (Ph.D dissertation, The Pennsylvania State University).

King F.J., Goodson, L., and Rohani, F. (1998). Higher- Order Thinking Skills: Definitions,Strategies,andAssessment.URL:http://www.cala.fsu.edu/files/higher order thinking_skills

Kusaeri, K., Hamdani, A. S., \& Suprananto, S. (2019). Student readiness and challenge in completing higher order thinking skill test type for mathematics. Journal of Mathematics Education, 8(1), 75-86.

Lee, M., \& Bong, M. (2019). Relevance of goal theories to language learning research. System, 86, 102122,115.

Lewis, A., \& Smith, D. (1993). Defining Higher Order Thinking. Theory into Practice. 32(3), 131 - 137.

Marshall, J. C., \& Horton, R. M. (2011). The relationship of teacher-facilitated, inquiry-based instruction to student higher-order thinking. School Science and Mathematics, 111(3), 93-101.

Marzano, R. J. (1993). How classroom teachers approach the teaching of thinking. Theory into Practice, 32(3), 154-159.

Ministry of Education. (2011). Basic education curriculum documents and as amended. Bangkok: Kurusapaladprao.

More and R. Parker. (1986). Critical Thinking Evaluation Claims and Argument in Everyday Life. California: Mayfield Publishing Co.

Najari, M., Babaei, F., Othmani, H., Karimi, A., \& Panahi, M. (2018). Investigating the Relationship between Lifestyle and Locus of Control in the Secondary High School Students in Bukan. European Journal of Behavioral Sciences, 1(1), 10-15.

National Institute of Educational Testing Service. (2018). Results from the O-NET of Academic Year of 2017, and Suggestions for the Policy Level. Bangkok: Agricultural Co-operative Federation of Thailand Printing Press.

O'Tuel FS, Bullard RK. (2001). Developing Higher Order Thinking in the Content Areas K-12. California: Critical Thinking Press and Software.

OECD. (2018). Education at a Glance 2018 OECD indicators. Paris: OECD Publishing.

Office of the Education Council. (2017). Education in Thailand. Bangkok: Prigwan Graphic. 
Olivier, E., Archambault, I., \& Dupéré, V. (2018). Boys' and girls' latent profiles of behavior and social adjustment in school: longitudinal links with later student behavioral engagement and academic achievement. Journal of School Psychology, 69, 28-44.

Pascarella ET, Wang JS, Trolian TL, Blaich C. (2013). How the instructional and learning environments of liberal arts colleges enhance cognitive development. Higher Educ. 66:569-583.

Perdana, R., Rudibyani, R. B., Budiyono, Sajidan, \& Sukarmin. (2020). The Effectiveness of Inquiry Social Complexity to Improving Critical and Creative Thinking Skills of Senior High School Students. International Journal of Instruction, 13(4), 477-490.

Perris, C., Jacobsson, L., Linndström, H., von Knorring, L., \& Perris, H. (1980). Development of a new inventory for assessing memories of parental rearing behavior. ActaPsychiatrica Scandinavica, 61(4), 265-274.

Rajendran, N., \& Idris, P. U. P. S. (2008). Teaching \& Acquiring Higher-Order Thinking Skills: Theory \& Practice: Penerbit Universiti Pendidikan Sultan Idris.

Ramos, J. L S., Dolipas, B.B., \&Villamore, B.B. (2013). Higher Order Thinking Skill and Academic Performance in Physics of College Student: A Regression Analysis. International Journal of innovative Interdisciplinary Research, 4, 48-60.

Reknes I, Visockaite G, Liefooghe A, Lovakov A and Einarsen SV. (2019) Locus of Control Moderates the Relationship Between Exposure to Bullying Behaviors and Psychological Strain. Front. Psycho, 6(10),1-12.

Rogers, C.R. (1969). Freedom to learn. Columbus: Charles E. Merrill Publishing Co.

Saido, G., Siraj, S., Bin Nordin, A., \& Al_Amedy, O. (2018). Higher Order Thinking Skills Among Secondary School Students in Science Learning. MOJES: Malaysian Online Journal of Educational Sciences, 3(3), 13-20.

Sidelinger, R. J., \& Booth-Butterfield, M. (2010). Co-constructing student involvement: An Examination of teacher confirmation and student-to-student connectedness in the college classroom. Communication Education, 59(2), 165-184.

Tanujaya, B. (2017). Mapping the HOTS of Senior High School Students in Mathematics Instructional Using Multidimensional Scaling. Paper Presented at The Third International Seminar on Quality and affordable Education, University of Malaya, Kuala Lumpur, Malaysia.

Torrance, P.E. (1962). Guilding Creative talen. New York: Prentice-Hall.

Van Dinther, M., Dochy, F., \&Segers, M. (2011). Factors affecting students' self-efficacy in higher education. Educational research review, 6(2), 95-108.

Vongpattaratrap K. (2014). Model for Identification of Causes of Critical Thinking Skills of Students in Prathomasueksa 6 (Year 6 of Elementary Level) under Office of Elementary Education Area 1, Phitsanulok Province.Unpublished M.Ed Thesis Project, Education Performance Evaluation, Graduate School of Pibulsongkram Rajabhat University.Thailand.

Vongtathum.P. (2015). The Effects of Interactive Learning Environment Model to Enhance the Creative Problem Solving Thinking for Computer Education Student Technical Education. Journal King Mongkut's University of Technology North Bangkok. 6(2), 32-39.

Wang, S., \& Wang, H. (2011). Teaching Higher Order Thinking in the Introductory MIS Course: A Model-Direct Approach. Journal Education for Business. 86, 208-212

Wiratchai N. (2000). Meta-analysis. Bangkok: Chulalongkorn University. 
Wolfradt, U., Hempel, S., \& Miles, J. N. (2003). Perceived parenting styles, depersonalisation, anxiety and coping behavior in adolescents. Personality and individual differences, 34(3), 521-532.

Zohar, A. and N. Schwartzer. (2005). Assessing Teachers'Pedagogical Knowledge in the Context of Teaching Higher-order Thinking. International Journal of Science Education. 27 (13), 1595-1620.

\author{
Esta obra está bajo una Licencia Creative Commons \\ Attribución-NoCommercial 4.0 International \\ $(\mathrm{cc})$ EY-NO
}

